\title{
Symbolic Violence and Resistance of Local Gold Miners to PT Indo Murokencana in Murung Raya Regency, Kalimantan Province
}

\author{
Pajarudinnoor $^{1}$, Ishomuddin ${ }^{2 *}$, Rinikso Kartono ${ }^{3}$, Tri Sulistyaningsih ${ }^{4}$ \\ ${ }^{1}$ Doctor of Sociology of University of Muhammadiyah Malang \\ ${ }^{2}$ Professor of Sociology of University of Muhammadiyah Malang \\ ${ }^{3}$ Doctor of Social Welfare, University of Muhammadiyah Malang \\ ${ }^{4}$ Doctor of Sociology, University of Muhammadiyah Malang
}

*Corresponding Author: Ishomuddin, Professor of Sociology, University of Muhammadiyah Malang

\begin{abstract}
This study is to understand the process of symbolic violence against local gold miners. Second, to describe forms of resistance by local miners to the state and PT. IMK. This research uses a social definition paradigm. This paradigm refers to the work of individual actions carried out because the individual considers something meaningful to himself and uses a qualitative approach. The qualitative approach is to prioritize process rather than results. The research data were presented emicently and analyzed qualitatively using the interaction model, Miles, Huberman and Saldana, namely data collection, data condensation, and drawing conclusions. Government to stop mining activities. However, the conditions that occurred in the PT. IMK continues to carry out activities by violating and ignoring environmental impacts and river pollution. PT. IMK without AMDAL documents in new clearing areas, not completing borrow-to-use forest area permits, violating the rights of indigenous peoples by displacing the sacred PurukKambang area and blocking access to natural resources in mining areas, said Arie Rompas, Executive Director of Walhi Central Kalimantan.
\end{abstract}

\section{INTRODUCTION}

Basically, the state exists to protect the rights and dignity of the people, where in this context the State gives people the assurance of a decent, prosperous and fair life. But in many cases, the state failed to show that it took sides with the people. On the contrary, the state takes coercive and destructive actions against society in order to protect and serve the interests of investors. Through the power of domination and hegemony it has, the state does everything it can to oppress and displace people from various forms of access or resources as life support for the people. On the other hand, the state provides protection to private parties, both in the form of legal protection and security protection (Haridison, 2013). [1].

The practice of state injustice as described above takes place systematically and massively in Indonesia. In many regions in Indonesia, there are many cases of community resistance to the state related to mining problems caused by the state's injustice actions against them as the people (Nainggolan, 2013) [2]. The Indonesian government easily grants permits to foreign companies to carry out mining exploration in many areas throughout Indonesia. On the other hand, the state does not seem to care about the surrounding communities where mining exploration takes place. Even the state takes coercive and destructive actions against the people in order to protect these foreign companies (Salim, 2017) [3]. On the other hand, foreign companies also often use state power to commit violence against communities around the mining exploration environment in the form of evictions, intimidation, oppression, and destruction (Nainggolan, 2013) [4].

One of the cases of state and capital owner violence against local communities in Indonesia is state violence and PT Indo MuroKencana (IMK) against traditional gold miners in Murung Raya Regency. In this case, it seems clear that the state is present to provide legal protection and security for PT Indo MuroKencana (IMK) to conduct gold mining exploration in Murung Raya Regency. Then, the state 
and the IMK took coercive and destructive actions against traditional gold miners in the form of evicting and destroying mining equipment belonging to traditional gold miners (WALHI, 2010) [5]. Traditional gold miners are excluded from mining exploration so they do not have a source of income to support their daily lives. In addition, the state and PT. IMK does not provide job opportunities for local people at PT. IMK. State violence and PT. The IMK is a form of state symbolic violence against local mining communities which ultimately has a negative impact on the lives of local communities.

The results of a study by the Commission for Missing Persons and Victims of Violence (KONTRAS) indicated that there were clashes between traditional mining communities and Brimob officers in the operational area of PT. Indo MuroKencana is a continuous case that is deliberately left alone without providing a sense of justice for the community (Mongabay, 2013a)[6]. So far, PT. Indo MuroKencana continues to neglect the environment and community rights and always uses a repressive approach that results in public anger which causes conflict and casualties between the apparatus and the community (Syahriansyah, 2019) [7]. The Forum for the Environment (WALHI) reveals the practice of PT Indo MuroKencana which always ignores the natural and social environment around it. PT. Indo MuroKencana continues to carry out activities by violating and ignoring the rights to the environment with river pollution, doing activities without AMDALl documents in new clearing areas, not completing lease-to-use forest area permits, violating the rights of indigenous peoples by displacing the sacred area of PurukKambang and closing access on natural resources in mining areas (WALHI, 2010) [8].

Local community resistance to the state and PT. IMK because the company continues to refuse to take responsibility for people's demands, and always involves the security forces in their disputes with the community. Not only that, IMK also carried out cruel practices in conflict management, through money politics, recruiting local residents to become security forces and forming local community teams who were rewarded for stifling people's struggles. All these efforts will eventually lead to horizontal conflicts between residents, whose seeds have started to grow in society (Kontras, 2013) [9]. In 2018, WALHI reported that the community fought against PT. IMK until violence occurred. The resistance started from PT. IMK accepts local people as PT. IMK. PT. IMK tends not to prioritize local personnel so that the community continues to push until they break into the PT. IMK which then happened violence (WALHI, 2010). [10]Basically, the state exists to protect the rights and dignity of the people, where in this context the State gives people the assurance of a decent, prosperous and fair life. But in many cases, the state failed to show that it took sides with the people. On the contrary, the state takes coercive and destructive actions against society in order to protect and serve the interests of investors. Through the power of domination and hegemony it has, the state does everything it can to oppress and displace people from various forms of access or resources as life support for the people. On the other hand, the state provides protection to private parties, both in the form of legal protection and security protection (Haridison, 2013) [11].

The practice of state injustice as described above takes place systematically and massively in Indonesia. In many regions in Indonesia, there are many cases of community resistance to the state related to mining issues caused by the state's injustice actions against them as the people. The Indonesian government easily grants permits to foreign companies to carry out mining exploration in many areas throughout Indonesia. On the other hand, the state does not seem to care about the surrounding communities where mining exploration takes place. Even the state takes coercive and destructive actions against the people in order to protect these foreign companies. On the other hand, foreign companies also often use state power to commit violence against communities around the mining exploration environment in the form of evictions, intimidation, oppression and destruction.

One of the cases of state and capital owner violence against local communities in Indonesia is state violence and PT Indo MuroKencana (IMK) against traditional gold miners in Murung Raya Regency. In this case, it seems clear that the state is present to provide legal protection and security for PT Indo MuroKencana (IMK) to conduct gold mining exploration in Murung Raya Regency. Then, the state and IMK took coercive and destructive actions against traditional gold miners in the form of evicting and destroying mining equipment belonging to traditional gold miners (WALHI, 2010). Traditional gold miners are excluded from mining exploration so they do not have a source of income to support their daily lives. In addition, the state and PT. IMK does not provide job opportunities for local people 
at PT. IMK. State violence and PT. The IMK is a form of state symbolic violence against local mining communities which ultimately has a negative impact on the lives of local communities.

Local community resistance to the state and PT. IMK because the company continues to refuse to take responsibility for people's demands, and always involves the security forces in their disputes with the community. Not only that, IMK also carried out cruel practices in conflict management, through money politics, recruiting local residents to become security forces and forming local community teams who were rewarded for stifling people's struggles. All these efforts will eventually lead to horizontal conflicts between residents, whose seeds have started to grow in society (Kontras, 2013). In 2018, WALHI reported that the community fought against PT. IMK until violence occurred. The resistance started from PT. IMK accepts local people as PT. IMK. PT. IMK tends not to prioritize local personnel so that the community continues to push until they break into the PT. IMK which then happened violence (WALHI, 2010). This study is to understand the process of symbolic violence against local gold miners. Second, to describe forms of resistance by local miners to the state and PT. IMK.

\section{LITERATURE REVIEW}

\subsection{Resistance}

The theory of resistance put forward by James Scott emphasizes that resistance is an activity aimed at reducing or rejecting the claims of the superdinate group. This theory can be divided into two, namely: closed resistance theory (hidden transcript) and open resistance (public transcript) (Scott, 1990) [12]. Open resistance is (1) organic, systematic and cooperative, (2) selfless, (3) revolutionary consequences, and / or, (4) negates the basis of domination (Scott, 1990). Closed resistance is characterized (1) irregular, unsystematic and occurring individually, (2) selfishness, (3) no revolutionary consequences, (4) more accommodating to the domination system (Scott, 1990). Scott's analysis is closer to the resistance that farmer groups are waging against landlords. But in the development of this theory, it can be used in the analysis of various cases, so that resistance language does not merely discuss resistance due to differences in the use of means of production, but differences in the structures of political power or others (Salim, 2017) [13]

Public transcripts are patterns of interaction, attitudes, behavior and images produced by the authorities in the public sphere. The ruling classes seek to establish the legitimacy of power that they are the ones who are worthy to lead and control the existing social order. Meanwhile the subordinate class appears to show obedience to the rules, norms and policies established by the ruling class. But there are patterns of informal interactions that are built by subordinate classes outside the control of the ruling class and underlie the formation of resistance, which James Scott calls Hidden Transcripts. So this results in the resistance carried out secretly by the subordinate class (Zainullah\& Jacky, 2017) [14].

In uncovering the power relationship between domination and resistance, Scott expressed two concepts about different patterns of interaction: Public Transcript and Hidden Transcript. Public transcripts are patterns of interactions that arise and occur in the public sphere between masters and slaves, employers and servants, employers and workers, authorities and subordinates, and so on. In the public sphere, the subordinate class shows its obedience to the rules established and controlled by the elite. Discourse in the public sphere seems to be controlled by the ruling class (Attamimi, 2014) [15]. However, the real elite class did not completely control the subordinate class. Because, there are patterns of informal interactions built by subordinate classes outside the control of the ruling class. This hidden pattern of interaction that only occurs between the subordinate class is what Scott calls the Hidden Transcript. Not only among the subordinate class, the ruling class also has its own Hidden Transcript (Scott, 1990) [16].

In contrast to Public Transcripts which show clearer appearance of attitudes and behavior patterns whose motives are deliberately hidden by actors, Hidden Transcripts are able to reveal forms of rejection of subordinate classes to elite class domination, or reveal various motives and interests hidden by elite classes. In the context of a subordinate class. Hidden transcripts are a form of resistance that is continuously conveyed only to trusted people and at a certain level it can lead to open confrontation (Yuwono, 2010) [17]. 
In the Public Transcript, the subordinate class has its own reasons and reasons for hiding resistance and showing obedience to the elite class. Likewise, the elite class needs various forms of justification with certain claims that legitimize its strength which the circle of subordinates can accept. In this case, there are always various possibilities and contradictions that occur in the intervention of Hidden Transcripts against Public Transcripts (Setiawan\&Ubaidullah, 2006) [18]. The public sphere often shows a harmonious arrangement among actors and is almost unrest. Outward appearances always deceive that there is actually a hidden conflict with the domination pattern. Based on certain considerations, the subordinate class did not engage in open rebellion, but preferred to take safer covert actions, such as covert destruction, theft and so on. The safest way to destroy domination is to spread a bad image for certain elites (Aisyah, 2018) [19]. In this case, subordinate resistance starts from the formation of discourse that is contrary to the dominant discourse. The hidden discourse built by this subordinate class is called Scott with the infrapolitical subordinate class.

However, in formal interactions, the subordinate classes seem to prefer adherence to the rules imposed by the dominant class. According to Scott, the tendency of the subordinate class to comply with the domination of the elite class can only be understood based on the external conditions surrounding their lives. Through the various considerations in its experience, the subordinate class chooses to obey and avoids the various risks that could befall it if it chooses to oppose. However, despite choosing to comply, the subordinate class is still looking for ways to channel their interests, even by taking advantage of the pattern of rules set by the dominant class (Scott, 1990) [20].

\subsection{Symbolic Violence}

Pierre Bourdieu (1930-2002) is a French sociologist and writer known for his vocal political views and involvement in public issues. Bourdieu is one of the leading players in French intellectual life. It became an "intellectual reference" for the movement against neoliberalism and globalization, which flourished in France and other parts of the world during the 1990s (Jolasa, 2009) [21]. The key terms are habitus, domain (field), and symbolic violence. It extends the notion of capital to categories such as social capital, cultural capital, and symbolic capital. For Bourdieu, every individual occupies a position in a multidimensional social space. This space is not determined by social class membership, but by the amount of each type of capital it has. Capital includes the value of social networks, which can be used to generate or reproduce inequality (Syahril, 2017) [22]. Some empirical examples, for example, show that although there appears to be freedom of choice in art, the artistic preferences of everyone (such as classical music, rock, pop, jazz, traditional music) are closely tied to their social position. Bourdieu also points out that differences in language such as accents, grammar, spelling and style - all of which are part of cultural capital - are major factors in social mobility. For example, to get a bigger salary, or get a job with a higher status (Grenfell, 2016) [23]. Bourdieu's work emphasizes how social classes, especially the intellectual and ruling classes, defend their social rights from generation to generation. This is seen despite the myth that contemporary post-industrial society marks equal opportunity and high social mobility, which is achieved through formal education (Hamzah, 2020) [24].

Bourdieu accepted Weber's view that society cannot be analyzed solely through economic class and ideology alone. Much of Bourdieu's work has to do with the independent role of educational and cultural factors. Instead of analyzing society through the concept of class, Bourdieu uses the concept of the domain (field), which is a social arena where people maneuver and struggle, in pursuit of coveted resources (Umanailo, 2018) [25]. Bourdieu extends Marcel Mauss' concept of habitus, although it also appears in the works of Aristotle, Norbert Elias, Max Weber, and Edmund Husserl. Bourdieu uses the concept of habitus in a systematic way in trying to solve the well-known antinomies in the humanities: objectivism and subjectivism (Ningtyas, 2015) [26]. Habitus can be defined as a system of dispositions (schemes of perceptions, thoughts and actions that are acquired and endure). Individual agents develop this disposition in response to the objective conditions they face. In this way, Bourdieu theorizes the inculcation of objective social structures into the mental and subjective experiences of agents. The objective social environment places the requirements for participants to become members, or say it, in the domain concerned (Umanailo, 2018) [27]. Hence, the objective social structure is therefore permeated into personal sets of cognitive and somatic dispositions. Meanwhile, the subjective structure of agent action is then equated with the objective structure and urgency that still exists in the social sphere. So Bourdieu sees the habitus as 
the key to social reproduction because it is important in generating and regulating the practices that shape social life. Individuals learn to yearn for what is possible for them, and not to aspire for things that are not available to them. The conditions in which the individual lives evoke dispositions that are appropriate to these conditions (including tastes in art, literature, food, and music), and in some cases pre-adapt to the demands of the conditions. The most unlikely practices are thus eliminated, as is inconceivable, by means of a kind of direct submission to a particular order. The order makes agents inclined to do something with pleasure, namely reject what is categorically rejected, and want the inevitable.

As noted above, Bourdieu employs methodological and theoretical concepts of habitus and the realm, with the aim of creating an epistemological break from the well-known objective-subjective antinomies in the social sciences. He effectively wanted to unify social phenomenology and structuralism. Bourdieu wants to reconcile material and symbolic consciousness and the unconscious, human freedom and attachment to structure, and economy and culture. Bourdieu tries to unify the concepts and practices of everyday life in society, and thereby overcomes the gap between theory and practice, between thought and action, and between ideas and concrete reality (Bourdieu, 1989) [28].

Habitus and domain are proposed to produce this gap, because they can only exist in relation to each other. Although a region is formed by the various social agents participating in it (and thus, in habitus), a habitus - as an effect - represents the transposition of the objective structure of the domain into the subjective structure of the agent's actions and thoughts. The relationship between habitus and realm is a two-way relationship. The realm can only exist as long as the social agent has a bias and a series of perceptual schemes, which are necessary to shape the domain and give it meaning (Attamimi, 2014) [28]. Simultaneously, by participating in realms, agents infused sufficient knowledge into their habitus, which would allow them to form realms. Habitus embodies the structure of nature, while nature mediates between habitus and practice. Bourdieu tries to use the concept of habitus and realm to remove the separation between subjective and objective. Whether Bourdieu succeeded or failed in his endeavors is open to debate. Bourdieu emphasized that every study must consist of two details. The first is the objective stage of research - where we look at relationships in social space and domain structures. Meanwhile, the second stage should be a subjective analysis of the disposition of social agents to act, as well as the categories of perceptions and understanding that emerge from the world's population. Adequate research, according to Bourdieu, cannot be done without these two things together.

\section{MeThodology}

This research uses the social definition paradigm (Ritzer). This paradigm refers to Weber's work. Individual action is carried out because the individual considers something meaningful to himself and uses a qualitative approach. The qualitative approach is to prioritize process rather than results. The research data was presented emic (verstehen) and analyzed qualitatively using the interaction model, Miles, Huberman and Saldana, namely data collection, data condensation, and drawing conclusions.

\section{DISCUSSION}

The conflict case between PT. Indo MuroKencana (IMK) with the Murang Raya community, the conflict was caused by mining activities to exploit natural resources. The mining area is a protected customary area and is the trust of the surrounding community. The area was designated as a customary area in 1994, as a cultural heritage site by the Central Kalimantan Education and Culture Office, with an inventory number 301 of 1993, and a regulation by the Governor of Central Kalimantan, to the Regent of KDH Tk II Barito Utara number 522.5 / 1916 / Ek, dated 7 November 1994. As well as a decision letter from the Directorate General of General Mining, Ministry of Mining and Energy to the board of directors of PT. IMK number 1809 A / 20 / DJP / 1994 dated September 30, 1994 regarding PurukKambang Preservation.Mining activities began when a policy was made to change customary forest areas to Raya Forest Areas (KHR). Changes in forest areas are the initial source of conflict, because the policy has received resistance from the community regarding changes in forest function. This is because the government does not involve local communities as inhabitants of customary forest areas and land owners in the policy making process. The government feels that the policy to change customary forest areas is important to exploit the natural resource wealth (gold) that is very potential in customary forest areas. This is evidenced by the existence of mining activities 
carried out by indigenous peoples traditionally for 50 years. In addition, the indigenous people of Murang Raya have traditionally carried out traditional mining activities as a livelihood. However, after the conversion of the customary forest area into a large forest area, it became a problem for the livelihoods of the Murang Raya community, given the large-scale exploitation of companies (contractors), so that the community lost their livelihoods. After the conversion of customary forest areas to large forest areas, the international scale mining company PT. Indo MuroKencana (IMK) which carries out mining activities. PT. IMK is a gold mining company $100 \%$ owned by Straits Resources Limited based in Perth, Australia. Gold mine owned by PT. This IMK is operated based on a third generation Contract of Work (KK) agreement with the Indonesian government which covers a concession area of approximately 47,940 ha in the District, Murung Raya, Central Kalimantan Province.

PT. IMK obtained a contract of work (KK) from President Suharto Number: B-07 / Pres / 1/1985 dated January 21, 1985. The implication of this COW was the granting of permission from the Indonesian government to PT. IMK to conduct gold mining exploitation activities in Permata Intan, Murung and Tanah Siang District, North Barito Regency. The contract of work for PT. IMK was valid for 30 years from February 1985 to 2014. Then PT. IMK received another permit in 2013, with a license number 17.K / 3 / DJB / 2013, the mining permit period 2013-2025, with the code for the Mining Business Permit Area (WIUP) 1300002062014115 Murang Raya Regency. (ESDM Minerba).

Mining activities of PT. IMK has become a serious threat to indigenous people who have long been gold miners and have lived around Mount Muro, North Barito, Central Kalimantan since 1982, little by little the Murang Raya community was evicted. PT. IMK continues to be responsive in its efforts to dominate the management of mining areas, from destroying people's lands to closing land access. Domination by PT. IMK has evicted local miners (bernuak) in Murang Raya Regency, and eliminated the jobs and income of the surrounding community. Apart from the domination of PT. IMK in carrying out mining activities, the people of Murang Raya also feel the impact of environmental damage due to the existence of PT. IMK has disposed of mining waste (Bartito Raya, 2020). As a result there is environmental pollution and water sources and rivers, such as the Pute, Manawing, Mangkahui rivers, and several surrounding sunagi which have become a source of livelihood for the community such as the Sarujan River, Salampong, Lahing, KalangTantatarai, Takukui, SangiranLika, SangiranMa'lu, Tino. , Hanjung, Mahaloe, Nangor, which are the rivers for disposal of waste from a power plant factory. Apart from environmental pollution to the river, there are also 33 mine pits not closed by PT. Indo MuroKencana (IMK). Environmental pollution occurs as a result of PT. Indo MuroKencana (IMK) provided by the government in fact violated several procedures, one of which was related to AMDAL. Based on the Mogabay report, the PT. Indo MuroKencana (IMK) in the form of arrears in payment for PT. Indo MuroKencana (IMK) covering an area of 47,940 hectares in Murang Raya Regency, Central Kalimantan. PT. Indo MuroKencana (IMK) has polluted the mine first before obtaining an environmental document permit.

\section{CONCLUSiON}

Based on the description in the research results and discussion section, this study concludes that: The conflict that occurred between the people of Murang Raya and PT. IMK was caused by administrative errors carried out by PT. IMK in determining the mining area, the determination of the mining area of PT. IMK violated the AMDAL permit and payment for operating land. As a result of mining activities, customary forest areas have been transformed into large forest areas, and have shifted the life and traditions of local communities. Mining activities carried out by PT. IMK has a significant environmental impact. The environmental impact caused by mining activities is polluting the rivers as a source of livelihood for the people of Murang Raya. Mining activities carried out in protected forest areas have shifted community activities as local miners which have been carried out for a long time, so that the presence of PT. IMK creates economic conflict and social conflict. Economic conflicts as a result of the loss of community acceleration from mining activities, and social conflicts as a result of state policies and PT. IMK. Mining management which is covered as an adminitasri practice of PT. IMK, with a development narrative accompanied by reforms should have an impact on the centralized management of natural resources. But PT. IMK does not heed and neglects communication to the local community, thereby eliminating cultural values that are the trust of the local indigenous people. Closed mining activities, prevented the community from having full access to land rights, and became employees of PT. IMK. That way the dominance of natural 
resources by PT. IMK is one of the factors causing conflict with the community, this domination which causes unfair administration and denial of the rights of local communities and indigenous peoples.

The domination of natural resources resulted in resistance from the Murang Raya community against PT. IMK, in facing community resistance, PT. IMK uses hard power to shift people's resistance. Community resistance to mining activities of PT. IMK has been carried out for a long time since President Soharto's era until now. In carrying out community resistance it tends to be consistent, but the approach to conflict resolution carried out by the state in conflict management tends to be coercive and hard power, resulting in casualties. However, in some cases the hard power approach has become the choice of the state because the state distracts the community from blocking the mining activities undertaken by PT Indo Muro.

Government to stop mining activities. However, the conditions that occurred in the PT. IMK continues to carry out activities by violating and ignoring environmental impacts and river pollution. PT. IMK without an AMDAL document in the new clearing area, has not completed a borrow-to-use forest area permit, violates the rights of indigenous peoples by displacing the sacred PurukKambang area and blocking access to natural resources in the mining area, said Arie Rompas, Executive Director of Walhi Central Kalimantan.

\section{REFERENCES}

[1] Haridison, A. (2013). Perjuangan Masyarakat Lokal dan Usaha Memberdayakan Diri (Studi Kasus Pertambangan Emas Rakyat di Merindu, Desa Konut, Kabupaten Murung Raya). /Ournal of Interdisciplinary Development Studies, XXI(1).

[2] Nainggolan, P. P. (2013). Kapitalisme Internasional Dan Fenomena Penjarahan Lahan Di Indonesia. Politica, 4(2), 225-262.

[3] Salim, M. N. (2017). Mereka yang Dikalahkan; Perampasan Tanah dan Resistensi Masyarakat Pulau Padang. March, 213.

[4] Nainggolan, P. P. (2013). Kapitalisme Internasional Dan Fenomena Penjarahan Lahan Di Indonesia. Politica, 4(2), 225-262. Nainggolan, P. P. (2013). Kapitalisme Internasional Dan Fenomena Penjarahan Lahan Di Indonesia. Politica, 4(2), 225-262.

[5] WALHI. (2010). Gambaran Konflik Masyarakat Adat Dayak Siang, Murung dan Bekumpai, Melawan PT. Indo Muro Kencan. WALHI. https://ayieffathurrahman.wordpress.com/2010/10/13/gambaran-konflikmasyarakat-adat-dayak-siang-murung-dan-bekumpai-melawan-pt-indo-muro-kencana.

[6] Mogabay. (2013). Indo muro kencana dari nmabang dn cagar budaya sampai pencemaran sungai di kalteng. Mogabay. https://www.mongabay.co.id/2013/03/23/indo-muro-kencana-dari-nambang-di-cagarbudaya-sampai-pencemaran-sungai-di-kalt

[7] Ningtyas, E. (2015). Pierre Bourdieu, Language and Symbolic Power. Jurnal POETIKA, 3(2). https://doi.org/10.22146/poetika.10437

[8] WALHI. (2010). Gambaran Konflik Masyarakat Adat Dayak Siang, Murung dan Bekumpai, Melawan PT. Indo Muro Kencan. WALHI. https://ayieffathurrahman.wordpress.com/2010/10/13/gambaran-konflikmasyarakat-adat-dayak-siang-murung-dan-bekumpai-melawan-pt-indo-muro-kencana

[9] Kontras. (2013). Aktivitas PT Indo Muro Kencana Harus Dihentikan. Majalah Fakta Online. http://majalahfaktaonline.blogspot.com/2013/07/aktivitas-pt-indo-muro-kencana-harus.html

[10] WALHI. (2010). Gambaran Konflik Masyarakat Adat Dayak Siang, Murung dan Bekumpai, Melawan PT. Indo Muro Kencan. WALHI. https://ayieffathurrahman.wordpress.com/2010/10/13/gambaran-konflikmasyarakat-adat-dayak-siang-murung-dan-bekumpai-melawan-pt-indo-muro-kencana

[11] Haridison, A. (2013). Perjuangan Masyarakat Lokal dan Usaha Memberdayakan Diri (Studi Kasus Pertambangan Emas Rakyat di Merindu, Desa Konut, Kabupaten Murung Raya). /Ournal of Interdisciplinary Development Studies, XXI(1).

[12] Scott, J. C. (1990). Domination and the Arts of Resistence Hidden Transcripts. YALE UNIVERSITY PRESS.

[13] Salim, M. N. (2017). Mereka yang Dikalahkan; Perampasan Tanah dan Resistensi Masyarakat Pulau Padang. March, 213.

[14] Zainullah, \& Jacky, M. (2017). Pola Resistensi Mahasiswa terhadap Dosen. Paradigma, 5(2), 1-13.

[15] Attamimi, L. (2014). Resistensi Warga Pinggir Rel Surabaya. http://repository.unair.ac.id/15848/ 
Symbolic Violence and Resistance of Local Gold Miners to PT Indo Murokencana in Murung Raya Regency, Kalimantan Province

[16] Scott, J. C. (1990). Domination and the Arts of Resistence Hidden Transcripts. YALE UNIVERSITY PRESS.

[17] Yuwono, A. E. (2010). Resistensi Masyarakat terhadap rencana pembangunan pabrik semen gresik di desa Kedumulyo kecamatan Sukolilo kabupaten Pati.

[18] Setiawan, D., \& Ubaidullah. (2006). Konflik dan Resistensi Masyarakat terhadap Pertambangan Galian C di Kabupaten Naga raya (Studi Kasus Desa Suak Plaembang Kecamatan Darul Makmur). Jurnal Ilmiah Mahasiswa FISIP Unsyiah, 4(2).

[19] Aisyah, S. M. (2018). Praktek Dominasi Kuasa dalam Paguyuban Duta Wisata (Studi Resistensi Anggota terhadap Tradisi dalam Paguyuban Cak Yuk di Gresik).

[20] Scott, J. C. (1990). Domination and the Arts of Resistence Hidden Transcripts. YALE UNIVERSITY PRESS.

[21] Jolasa, V. (2009). Pierre Bourdieu dan Pemikirannya tentang Habitus, Doxa dan Kekerasan Simbolik. Pierre Bourdieu Dan Pemikirannya Tentang Habitus, Doxa Dan Kekerasan Simbolik.

[22] Syahril. (2017). Arena Cultural Production Symbolic and Violence ( Analysis of Novel Banat al-Riyadh Pierre Bourdieu Sociology Perspective ). August.

[23] Grenfell, M. (2016). Pierre Bourdieu: Key Concepts. In Acumen (Issue 101). https://doi.org/10.4324 /9781315453859-11

[24] Hamzah, A. A. (2020). Pierre Bourdieu dan gagasanya Mengenai Agama. Citra Ilmu, 1(11), 7-8.

[25] Umanailo, M. C. B. (2018). Mengurai Kekerasan Simbolik di Sekolah: Sebuah pemikiran Pierre Bourdiue Tentang Habitus dalam Pendidikan (Issue March). https://doi.org/10.13140/RG.2.2.24809.80483

[26] Ningtyas, E. (2015). Pierre Bourdieu, Language and Symbolic Power. Jurnal POETIKA, 3(2). https://doi.org/10.22146/poetika.10437

[27] Umanailo, M. C. B. (2018). Mengurai Kekerasan Simbolik di Sekolah: Sebuah pemikiran Pierre Bourdiue Tentang Habitus dalam Pendidikan (Issue March). https://doi.org/10.13140/RG.2.2.24809.80483

[28] Bourdieu, P. (1989). The Field of Cultural Production. Columbia University Press.

[29] Attamimi, L. (2014). Resistensi Warga Pinggir Rel Surabaya. http://repository.unair.ac.id/15848/

\section{AUTHORS' BIOGRAPHY}

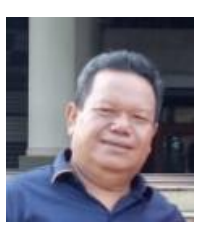

Pajarudinnoor, is Doctor of Sociology at the University of Muhammadiyah Malang

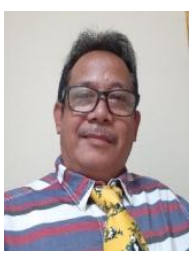

Ishomuddin, is Professor of Sociology of University of Muhammadiyah Malang

Citation: Ishomuddin, et.al. "Symbolic Violence and Resistance of Local Gold Miners to PT Indo Murokencana in Murung Raya Regency, Kalimantan Province" International Journal of Humanities Social Sciences and Education (IJHSSE), vol 7, no. 11, 2020, pp. 60-67. doi: https://doi.org/10.20431/23490381.0711008 .

Copyright: (c) 2020 Authors. This is an open-access article distributed under the terms of the Creative Commons Attribution License, which permits unrestricted use, distribution, and reproduction in any medium, provided the original author and source are credited. 